\title{
Amikacin, Ceftazidime, and Flucloxacillin against Suspended and Adherent Pseudomonas aeruginosa and Staphylococcus epidermidis in an In Vitro Model of Infection
}

\author{
Patrice Vergères and Jürg Blaser
}

Divisions of Infectious Diseases and Medical Informatics, Department of Medicine, University Hospilal, Zurich, Swizzerland

\begin{abstract}
Bacterial inocula were exposed as suspended cultures or as adherent biofilms on glass beads in a novel in vitro model of infection to oscillating drug concentrations mimicking human serum kinetics during clinical treatment. Amikacin was given once or thrice daily alone or in combination with ceftazidime or flucloxacillin against Pseudomonas aeruginosa or Staphylococcus epidermidis. Killing of adherent bacteria was significantly reduced during single-drug treatment compared with suspended bacteria $(P<.001)$, and $\beta$-lactams were more active than amikacin against both suspended and adherent bacteria $(P<.01)$. Amikacin- $\beta$-lactam combinations killed the inocula more rapidly and were consistently bactericidal against both suspended and adherent pathogens $(P<.05)$. Once-daily dosing of amikacin produced greater initial killing than thrice daily dosing $(P<.05)$, but both regimens were similarly effective after $48 \mathrm{~h}$. The differences in antibiotic activity against suspended and adherent bacteria may relate to clinical failures in the treatment of foreign-body infections by bacteria sensitive to the administered antibiotics, as determined by standard susceptibility tests.
\end{abstract}

Antibiotic treatments of foreign-body infections without removal of the infected implants often fail even if the pathogens are highly susceptible as determined by standard in vitro tests $[1,2]$. It has been suggested that the mode of growth of bacteria adhering to metallic or polymeric implants and the formation of a biofilm by bacterial secretion of extracellular glycocalix may explain such failures [3-6]. It has also been advocated that restricted drug penetration through thick bacterial biofilms may limit therapeutic efficacy of antibiotics during treatment of other than implant-related infections, such as osteomyelitis or endocarditis [7,8].

Various animal models of implant-associated infections have been used to search for effective antimicrobial treatment of foreign-body infections $[9,10]$. Recently, in vitro studies also considered the effect of constant concentrations of antibiotics against both adherent and suspended bacteria $[11,12]$. However, in vitro models of bacterial infection exposing bacteria to fluctuating concentrations of antibiotic according human pharmacokinetics have been limited so far to the study of suspended cultures [13,14].

This study presents a novel pharmacodynamic model that considers quantitatively the activity of antimicrobial agents against both adherent and suspended bacteria, mimicking prolonged bacterial exposure to oscillating drug levels according to human serum kinetics.

Received 15 April 1991; revised 13 September 1991

Grant support: Swiss National Research Foundation (3.913.0.85).

Reprints or correspondence: Dr. Jürg Blaser, Department of Medicine, University Hospital Zürich, Rämistrasse 100, CH-8091 Zürich. Switzerland

The Journal of Infectious Diseases 1992;165:281-9

(c) 1992 by The University of Chicago. All rights reserved.

$0022-1899 / 92 / 6502-0013 \$ 01.00$

\section{Materials and Methods}

In vitro model. A one-compartment pharmacokinetic model that provides exposure of bacteria to changing concentrations of antimicrobial agents was used. In contrast to previously described in vitro models, the design of the culture compartment of this model allows for periodic assessment of the bactericidal effect against both adherent and suspended bacteria. Figure 1 is a schematic diagram of the model, including a cross-section through a $17-\mathrm{ml}$ culture compartment. During the experiment with adherent bacteria, glass beads covered with a bacterial biofilm were added to a wire cage within the compartment for inoculation. Subsequently these beads were removed at various sampling times. During each experiment, three models inoculated with suspended cultures and three with adherent inocula were set up simultaneously.

The system was filled with tryptic soy broth (TSB) supplemented with $50 \mu \mathrm{g}$ of $\mathrm{Ca}^{2+} / \mathrm{ml}$ and $25 \mu \mathrm{g}$ of $\mathrm{Mg}^{2+} / \mathrm{ml}$ (TSB-S). A peristaltic pump continuously transported antibiotic-free broth from the reservoir into the compartment. Antibiotic doses administered into the culture compartments were eliminated exponentially, due to continuous perfusion of the compartment. Concentration-time profiles were achieved according to human serum kinetics by defining the flow rate of the pump (clearance, $\mathrm{Cl}$ ) in function of the volume of the culture compartment (V) and the elimination half-life $\left(t_{1 / 2}\right)$ as $C l=\ln 2 \times V / t_{1 / 2}$.

Dosage regimens. Antibiotic doses were chosen to achieve drug concentrations similar to mean concentrations achieved clinically in patients during administration of daily doses of $3 \mathrm{~g}$ of ceftazidime or flucloxacillin (floxacillin) or $15 \mathrm{mg} / \mathrm{kg}$ amikacin. The following drug regimens were tested either alone or in combination over a 48 -h period: (1) ceftazidime regimen, given as a loading dose to rapidly achieve a steady-state concentration of $16 \mathrm{mg} / \mathrm{l}$ followed by a 48 -h continuous infusion; (2) flucloxacillin regimen, given as loading dose to rapidly achieve a steadystate concentration of $2 \mathrm{mg} / \mathrm{l}$ followed by a 48 -h continuous 


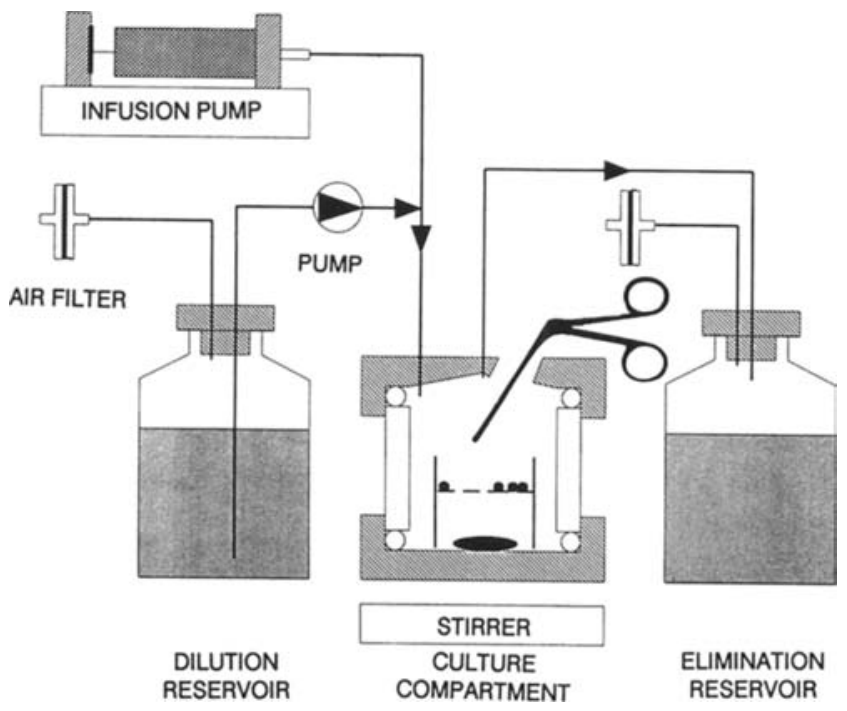

Figure 1. Schematic drawing of one-compartment kinetic model. Inocula of Pseudomonas aeruginosa and Staphylococcus epidermidis were added to culture compartment as suspended bacterial cultures or as biofilms of bacteria adhering to beads. Beads were removed from time to time from compartment with surgical forceps after opening tightly sealed port. Amikacin was administered into compartment as $1-\mathrm{h}$ infusions and removed exponentially due to continuous dilution with drug-free medium.

infusion; (3) regimen $\mathrm{Aq} 24$, a 1 -h infusion of amikacin at $0 \mathrm{~h}$ and $24 \mathrm{~h}$ to provide peak concentrations of $72 \mathrm{mg} / \mathrm{l}$ and troughs of $<0.1 \mathrm{mg} / \mathrm{l}$, according to a 2-h elimination half-life; and (4) regimen Aq8, $1-\mathrm{h}$ infusions of amikacin given every $8 \mathrm{~h}$ with an initial peak concentration of $24 \mathrm{mg} / \mathrm{l}$ and a trough level of 2 $\mathrm{mg} / \mathrm{l}$, according to a half-life of $2 \mathrm{~h}$. Concentrations of amikacin achieved in the culture compartment were measured by fluorescence polarization immunoassay (TDx; Abbott Laboratories, Abbott Park, IL). The differences between the measured and the calculated concentrations averaged $6 \%$ (mean of 24 measurements). Amikacin was administered by a syringe infusion pump. Continuous infusions of ceftazidime and flucloxacillin were achieved by adding the drug to sterile broth kept at room temperature outside the $37^{\circ} \mathrm{C}$ incubator.

Bacteria. Four strains were used: Pseudomonas aeruginosa ATCC 27853 and S64, a clinical isolate from a cystic fibrosis patient, and Staphylococcus epidermidis V2, slime-producing [15] (provided by G. Peters, Cologne, Germany), and B3972, a clinical isolate [1]. MICs were determined by broth dilution technique, using inocula of $\sim 5 \times 10^{5}$ colony-forming units $(\mathrm{cfu}) / \mathrm{ml}$ in 2-ml volumes. $\mathrm{MBCs}$ were determined as $>99.9 \%$ killing of the bacterial inocula. Quantitative subcultures were obtained of each tube by filtering $100-\mu$ l volumes through membrane filters with $0.45-\mu \mathrm{m}$ pore size (Sartorius, Göttingen, Germany) and subsequently culturing the filters on agar. For both strains of $P$. aeruginosa, the MICs were $8 \mathrm{mg} / \mathrm{l}$ for amikacin and $4 \mathrm{mg} / \mathrm{l}$ for ceftazidime. The MICs for $S$. epidermidis $\mathrm{V} 2$ were $1 \mathrm{mg} / \mathrm{l}$ for amikacin and $0.25 \mathrm{mg} / 1$ for flucloxacillin and for strain B3972, $8 \mathrm{mg} / \mathrm{l}$ for amikacin and $1 \mathrm{mg} / \mathrm{l}$ for flucloxacillin. All MBCs were either identical to the MICs or twofold higher.

MICs were also determined with inocula from released adher- ent bacteria. These inocula were obtained by vortexing beads covered with bacterial biofilms to remove the adherent population from the surface and bring the bacteria into suspension. All MICs were identical except for twofold higher results obtained with amikacin against $P$. aeruginosa S64 and S. epidermidis V2 and B3972.

Suspended inocula. Volumes of $0.6-1 \mathrm{ml}$ of overnight cultures were added to $17 \mathrm{ml}$ of broth within the culture compartments $30 \mathrm{~min}$ before drug administration, yielding mean inocula of suspended bacteria of $4.3 \times 10^{6} \mathrm{cfu} / \mathrm{ml}$. For each strain, the suspended inocula were adjusted to achieve total numbers of suspended bacteria within the compartments of about two times higher than the bacterial numbers inoculated by adherent biofilms. Thus, lower activity against adherent inocula did not relate to an inoculum effect.

To study the effect of amikacin treatment against bacteria in the stationary phase of growth, TSB-S as the culture medium was completely replaced in the in vitro model by $0.25 \%$ glucosesupplemented PBS, pH 7.4 (PBS-S). Volumes of $0.8 \mathrm{ml}$ overnight culture in TSB-S were cooled in a syringe in $20 \mathrm{~min}$ from $37^{\circ} \mathrm{C}$ to $\sim 4^{\circ} \mathrm{C}$ and subsequently added to $17 \mathrm{ml}$ of PBS-S within the culture compartments $30 \mathrm{~min}$ before drug adminstration.

Adherent inocula. Sterile solid glass beads (diameter, 2-3 $\mathrm{mm}$ ) or sinter glass beads containing pores of 60-300 $\mu \mathrm{m}$ (Sikug 023/300/A; Schott Schleifer, Muttenz, Switzerland) were placed into $20-\mathrm{ml}$ cultures of TSB-S that were inoculated with two colonies taken from a blood agar plate and incubated overnight. The solid glass beads were removed from the overnight cultures and placed into $25 \mathrm{ml}$ of sterile saline solution $(0.9 \%$ $\mathrm{NaCl}$ ) for washing off bacteria suspended within the broth carried over. Overnight broth was separated from sinter glass beads by placing the beads on filters and rinsing them with 10 $\mathrm{ml}$ of sterile saline solution. The culture compartments of the model were inoculated with 12 solid or sinter glass beads that were placed into the compartments with a sterile surgical forceps.

Quantification of bactericidal activity. During the experiments with suspended bacterial inocula, $0.3-\mathrm{ml}$ specimens of the culture medium were sampled from each culture compartment seven times within the 48-h treatment period (at $0,2,6$, $24,26,30$, and $48 \mathrm{~h}$ ) to document the number of suspended cfu over time. During experiments with adherent bacterial inocula, $0.3-\mathrm{ml}$ specimens of the culture medium and one bead were removed from the culture compartment at each of the seven sampling points with a sterile surgical forceps. This bead was placed into a tube containing $2 \mathrm{ml}$ of sterile broth. Bacteria adhering to the glass bead were removed by vigorously vortexing the tube three times for $15 \mathrm{~s}$. Longer vortexing or additional treatment in an ultrasonic bath increased the cfu counts by $<2 \%$. In addition, tubes containing the beads were incubated for $48 \mathrm{~h}$. Eradication of the adherent bacterial inocula was defined as tubes showing no visible growth after $48 \mathrm{~h}$ of incubation.

Specimens of the broth in which the beads had been vortexed were subsequently processed similarly to specimens withdrawn directly from the culture compartments. Each sample was diluted 100-fold and subcultured on tryptic soy agar plates using a spiral plater (Spiral System Instruments, Bethesda, MD). In addition, $100 \mu$ l of each sample was filtered through a membrane 


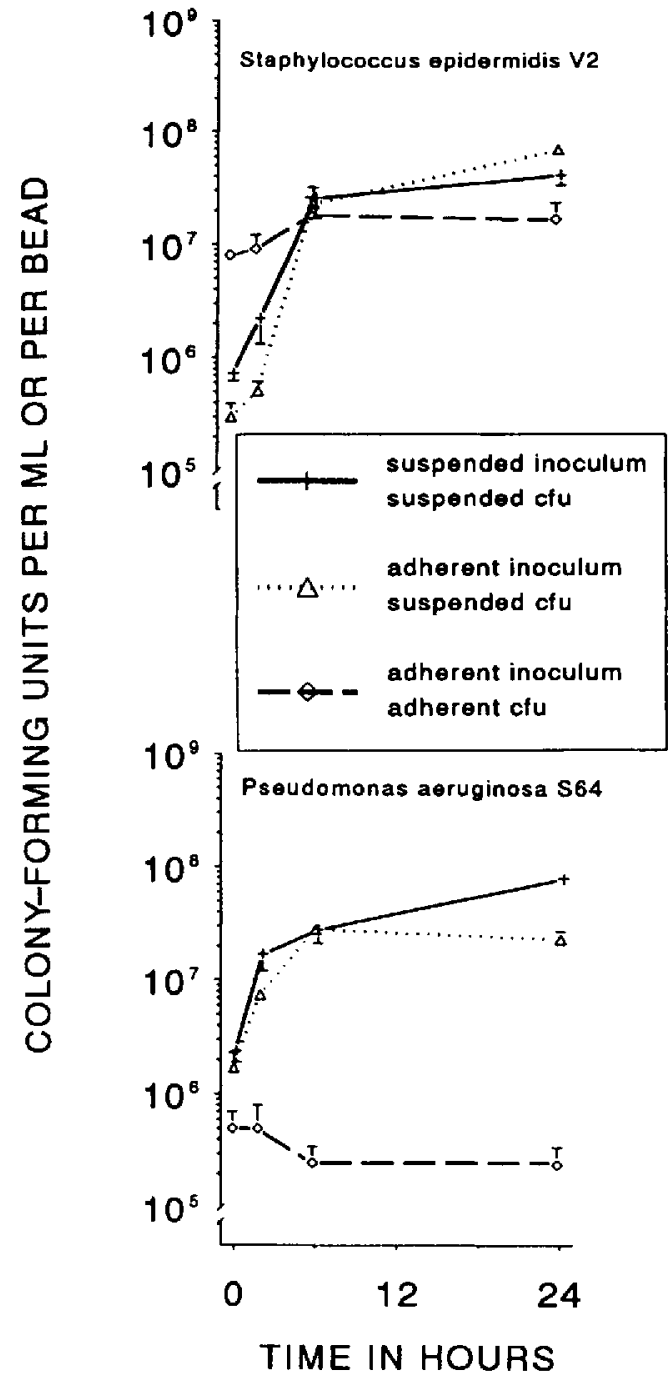

Figure 2. Control growth curves in absence of any antibiotics for Staphylococcus epidermidis V2 and Pseudomonas aeruginosa S64 in one-compartment in vitro model. Inocula were administered as suspended cultures (colony-forming units per milliliter $[\mathrm{cfu} / \mathrm{ml}]$ in broth) or as bacterial biofilm adhering to glass beads (cfu/ml shed bacteria suspended in broth and cfu of adherent bacteria per sinter glass bead). Geometric means and SD of two replicates are shown.

filter of $0.45-\mu \mathrm{m}$ pore size. Subsequently the filters were placed on agar and incubated at $37^{\circ} \mathrm{C}$. Bacterial colonies growing on the agar were counted (Laser Bacteria Colony Counter model 500A; Spiral System Instruments), and the number of cfu per milliliter $(\mathrm{cfu} / \mathrm{ml})$ was calculated. The incubation time varied from 16 to $48 \mathrm{~h}$ hours, depending on the strain and whether the specimens were plated directly on agar or subcultured on a filter.

Control growth curves in the absence of any drug were also obtained for both adherent and suspended inocula with all strains. Figure 2 shows curves for $S$. epidermidis V2 and P. aeruginosa S64. Similar results were obtained with the two other strains. The limited initial decrease of adherent cfu was observed with both strains of $P$. aeruginosa but not with $S$. epidermidis.

Assessment of removal of adherent bacteria. Both sterile solid and sinter glass beads were placed in $2 \mathrm{ml}$ of TSB-S containing $20 \mu \mathrm{Ci}$ of $\left[{ }^{3} \mathrm{H}\right]$ thymidine (specific activity, $29 \mathrm{Ci} / \mathrm{mmol}$; Amersham Laboratories, Amersham, UK). After inoculation with one colony taken from a blood agar plate, these cultures were incubated overnight. Then beads were removed from cultures, placed on filters, and rinsed with sterile saline solution $(0.9 \%$ $\mathrm{NaCl}$ ) to remove suspended bacteria and unincorporated $\left[{ }^{3} \mathrm{H}\right]$ thymidine. Three beads were transferred to three scintillation vials each containing $3 \mathrm{ml}$ of scintillant (Opti-Fluor; Packard Instruments, Downers Grove, IL). Another three beads were placed in three tubes each containing $2 \mathrm{ml}$ of sterile broth. Bacteria adhering to the beads were removed from the beads by vigorously vortexing the tubes three times for $15 \mathrm{~s}$. Samples $(100 \mu \mathrm{l})$ of the broth were transferred to the vials containing scintillant. In addition, the beads were washed on filters to remove suspended bacteria in broth and also transferred to scintillation vials. The amount of radioactivity retained on beads and in broth was measured with a liquid scintillation analyzer (2200CA; Packard Instruments). Controls with sterile beads in broth without radiolabeled thymidine were also measured in triplicate. In addition, removal of unincorporated $\left[{ }^{3} \mathrm{H}\right]-$ thymidine from beads by the washing and vortexing procedure was controlled in overnight samples without bacteria. Similar results were obtained with both control methods. The counts per minute (cpm) of three vials were averaged, and cpm of control beads without radiolabeled thymidine were subtracted. The remaining radioactivity on beads after vortexing was compared with the activity before vortexing to determine the efficacy of removal by vortexing.

Postexposure susceptibility testing. Subpopulation analysis was done during experiments with ceftazidime against adherent inocula of $P$. aeruginosa S64 and with amikacin (Aq8) against adherent inocula of $S$. epidermidis V2. Samples of adherent bacteria (released from the beads by vortexing) and suspended bacteria shed from the biofilm were diluted appropriately and were cultured on TSB agar plates containing no antibiotics and plates containing 1,4 , or $16 \mathrm{mg} / \mathrm{l}$ amikacin or 4,8 , or $16 \mathrm{mg} / 1$ ceftazidime.

Data analysis. Geometric means were used to describe the average number of cfu determined in multiple experiments. If no cfu were detected in a $100-\mu \mathrm{l}$ sample, a value of $10 \mathrm{cfu} / \mathrm{ml}$ was arbitrarily used for the calculation of the geometric mean. Response during the initial 6-h treatment period and during the total $48-\mathrm{h}$ treatment period was analyzed by logarithmic transformation of the cfu data followed by analysis of variance. Further comparisons were done by the Scheffe $F$ test. Initial dose response $(0-6 \mathrm{~h})$ was compared with response of doses after $24 \mathrm{~h}$ of treatment $(24-30 \mathrm{~h})$ for each treatment with the paired $t$ test (figure 3 ). Percentage of resistant subpopulations was studied by analysis of variance after logarithmic transformation.

\section{Results}

Suspended inocula of $P$. aeruginosa. Treatment with amikacin alone produced an initial killing (mean reduction of both strains after $6 \mathrm{~h}$ ) of $4.2 \log _{10}$ during Aq 8 regimens and $>5$ log during Aq24 regimens. However, strain 27853 regrew to bacterial densities of $\sim 10^{4} \mathrm{cfu} / \mathrm{ml}$ within $24 \mathrm{~h}$ of treatment with either regimen. No bactericidal effect occurred 


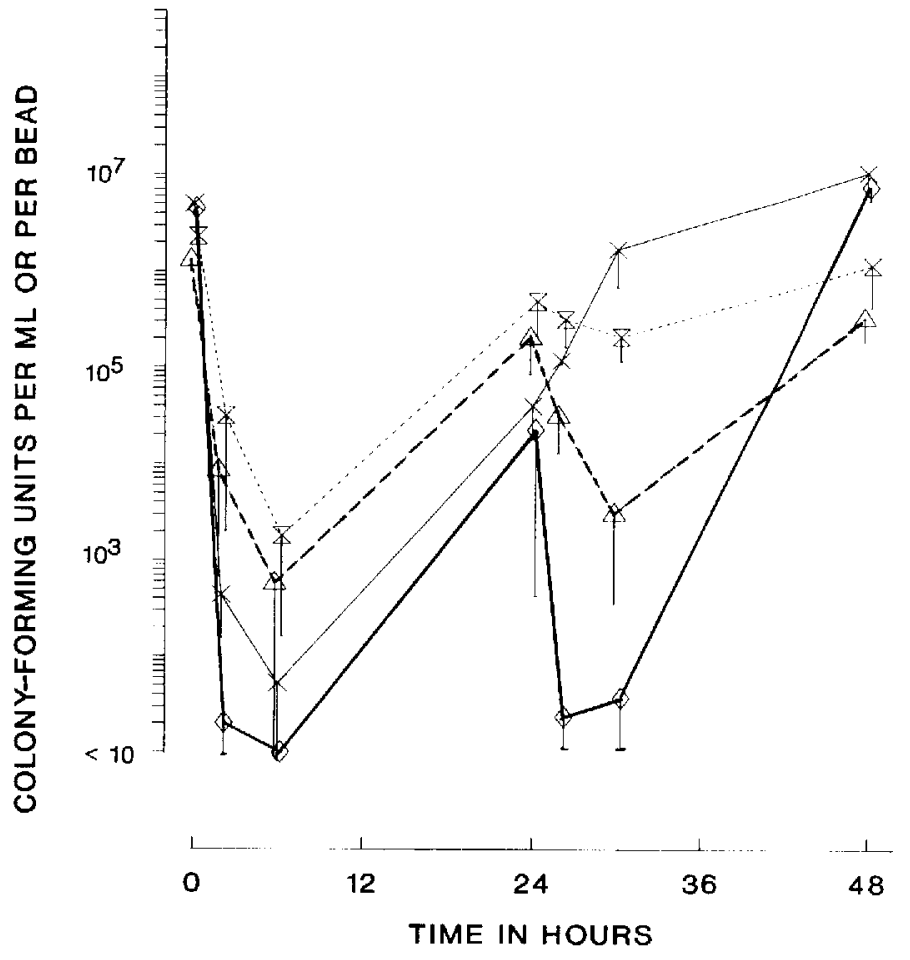

Figure 3. Effect of amikacin administered once (thick lines) or trice daily (thin lines) against Pseudomonas aeruginosa 27853 in one-compartment in vitro model. Bactericidal activity was studied in experiments with either suspended (solid lines) or adherent inocula (broken lines, adherent colony-forming units recovered from beads). In contrast to first dose, doses administered after $24 \mathrm{~h}$ showed significantly less bactericidal activity $(P<.01)$. Geometric means and SD of two or three replicates are shown.

with strain 27853 after the dose given after $24 \mathrm{~h}$ during the Aq8 regimen. In contrast, the second dose during once-daily treatment still reduced the count of $\mathrm{cfu} / \mathrm{ml}$ from $2.5 \times 10^{4}$ at $24 \mathrm{~h}$ to 35 at $30 \mathrm{~h}$ (figure 3). Strain $\mathrm{S} 64$ showed no regrowth within the first $24 \mathrm{~h}$ of treatment with both regimens, despite the prolonged period of subinhibitory concentrations of $17 \mathrm{~h}$ before administration of the second dose with regimen Aq24 (figure 4). However, both strains did regrow within the 48-h treatment period with either dosing schedule. Ceftazidime alone produced rapid initial killing of $P$. aeruginosa S64 $(>4.4 \mathrm{log}$ reduction within $6 \mathrm{~h}$, figure 4$)$. Strain 27853 was killed slower $(1.5 \mathrm{log})$ despite identical MICs of both strains. However, after $48 \mathrm{~h}$ of treatment, both strains were reduced below the detection limit in four of five experiments (in one experiment with strain $27853,2.3 \times 10^{2} \mathrm{cfu} / \mathrm{ml}$ were found). The combination regimens produced more rapid initial killing $(<10 \mathrm{cfu} / \mathrm{ml}$ after $6 \mathrm{~h}$ ) of both strains with no subsequent regrowth (figure 4 ).

Adherent inocula of $P$. aeruginosa. Adherent bacteria of $P$. aeruginosa $\mathrm{S} 64$ showed no response to treatment with the Aq8 regimen (figure 4); there was no significant difrerence detectable between this regimen and the control growth curve (figure 2). In contrast, adherent bacteria of strain

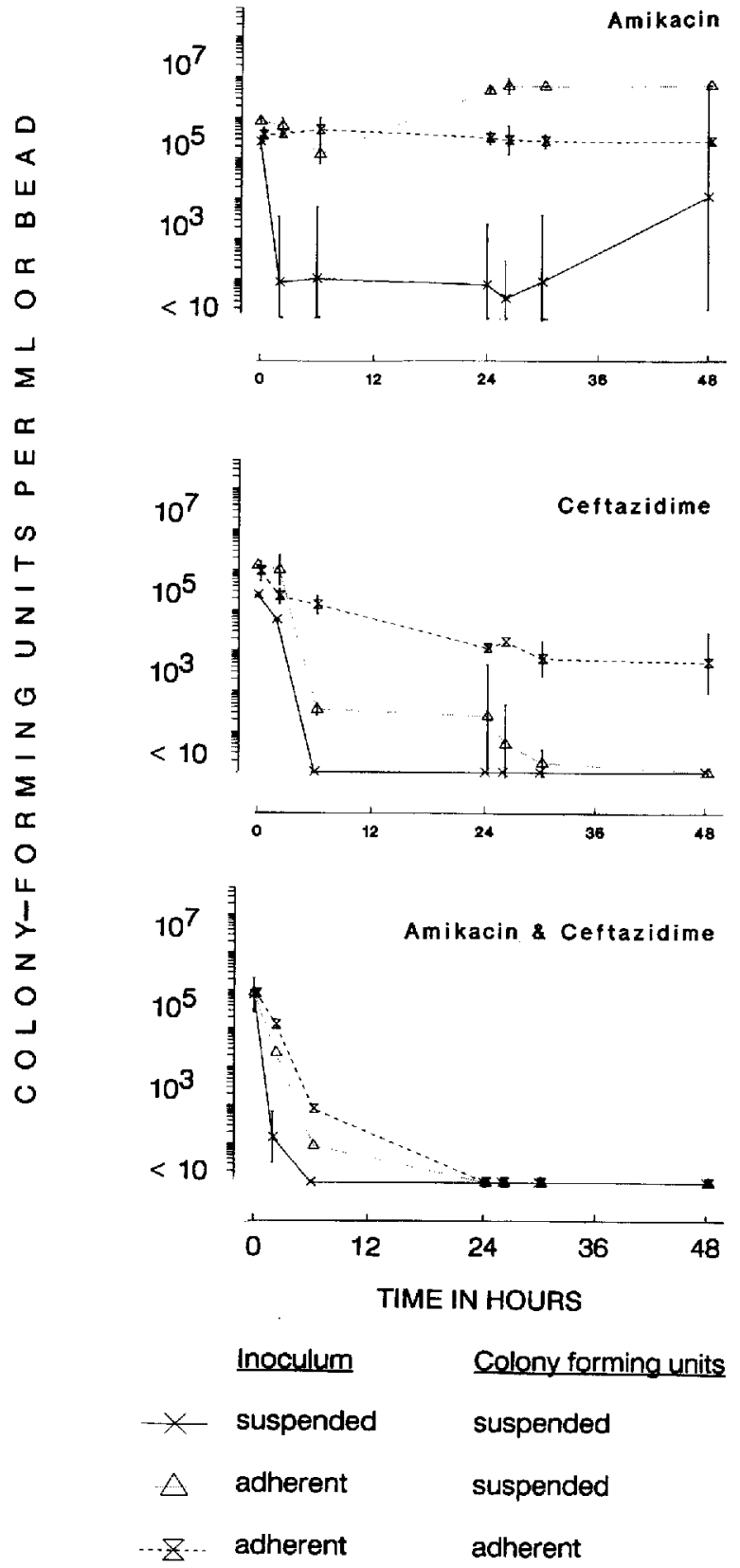

Figure 4. Effect of amikacin (thrice daily), ceftazidime (loading dose followed by continuous infusion), and combination of both drugs against Pseudomonas aeruginosa S64 in one-compartment in vitró model. Significantly $(P<.01)$ better early bactericidal activity was observed in experiments using initial inoculum of suspended bacteria (colony-forming units per milliliter $[\mathrm{cfu} / \mathrm{ml}]$ in broth) compared with results using initial inoculum of bacteria adherent to glass beads ( $\mathrm{cfu} / \mathrm{ml}$ shed from solid glass beads and suspended in broth and cfu adhering to each sinter glass bead). Geometric means and SD of two or three replicates are shown.

27853 were initially reduced by $3.1 \log$ (figure 3 ). Doses given after $24 \mathrm{~h}$ with the $\mathrm{Aq} 8$ regimen showed almost no bactericidal effect with either strain (0.1-0.4 log killing, figure 4). Regimen Aq24 reduced the adherent bacteria of both strains within the first $6 \mathrm{~h}$ by 3.4 and $3.5 \mathrm{log}$, respectively 
(figure 3 ). The second dose given after $24 \mathrm{~h}$ was less effective. Strain $\$ 64$ showed nearly no response to the second dose ( 0.3 log killing), and strain 27853 was reduced by 1.8 $\log$ (figure 3 ). Both strains responded similarly to singleagent treatment with ceftazidime: Adherent bacteria were killed continuously but very slowly, resulting in a reduction of only $2.3 \mathrm{log}$ for strain $\$ 64$ (figure 4) and $1.2 \mathrm{log}$ for strain 27853 after $48 \mathrm{~h}$. However, combinations of ceftazidime with either $\mathrm{Aq} 8$ or $\mathrm{Aq} 24$ produced rapid initial killing of adherent bacteria of both strains, and no subsequent regrowth occurred (table 1).

Although inocula were administered as biofilms of bacteria adhering to glass beads, bacteria were also found in suspension due to continuous shedding of cells from the biofilm into the liquid culture medium. The initial response to the Aq 8 and $\mathrm{Aq} 24$ regimens observed during these experiments against shed suspended bacteria (in the presence of biofilmcovered glass beads) were 0.8 and $4.6 \mathrm{log}$ killing after $6 \mathrm{~h}$ with strain S64 and 3.0 and $5.1 \mathrm{log}$ killing with strain 27853, respectively (figure 4 ). Both strains regrew also in suspension with either amikacin regimen. In contrast, ceftazidime administered alone killed shed suspended $P$. aeruginosa S64 rapidly $(3.6 \mathrm{log}$ reduction after $6 \mathrm{~h}$ ), followed by a steady decline during the remaining $42 \mathrm{~h}$. Shed cells of $P$. aeruginosa 27853 were killed less rapidly by ceftazidime. The initial effect was limited to $1.2 \mathrm{log}$ reduction, and after $48 \mathrm{~h}$ of treatment there were still $1000 \mathrm{cfu} / \mathrm{ml}$ present. Combinations of ceftazidime and amikacin $\mathrm{Aq} 8$ or $\mathrm{Aq} 24$ synergistically killed shed suspended bacteria. Strain $\mathbf{S 6} 4$ was reduced below the sensitivity limit after $6 \mathrm{~h}$ of treatment and strain 27853 after $24 \mathrm{~h}$, with no subsequent regrowth.

Suspended inocula of $S$. epidermidis. The response to amikacin regimens was different for the two strains studied due to different antibiotic sensitivities. The inoculum of the highly sensitive strain V2 (amikacin MIC $=1 \mathrm{mg} / \mathrm{l}$ ) was reduced after $6 \mathrm{~h}$ of exposure to amikacin by $5.2 \log \mathrm{cfu} / \mathrm{ml}$ (Aq8; figure 5) and $5.7 \mathrm{log} \mathrm{cfu} / \mathrm{ml}$ (Aq24). After $24 \mathrm{~h}$ of treatment, limited regrowth $\left(5 \times 10^{4} \mathrm{cfu} / \mathrm{ml}\right)$ occurred with regimen $\mathrm{Aq} 24$ but not with $\mathrm{Aq} 8$. However, both amikacin regimens reduced this strain below the detection limit after $48 \mathrm{~h}$ of treatment.

Two additional experiments were done to elucidate further the activity of amikacin against $S$. epidermidis V2. In one experiment, suspended inocula were obtained by release of adherent bacterial populations to determine whether the compromised activity against adherent bacteria relates to intrinsically higher resistance of bacteria grown in biofilms or whether adherently grown, released bacteria are similarly sensitive to amikacin as populations grown in suspension. Released adherent inocula were prepared by vortexing biofilm-covered beads similar to the procedure used to quantify adherent $\mathrm{cfu}$. After $6 \mathrm{~h}$ of treatment with amikacin Aq8, the initial inoculum was reduced by $>6.2 \mathrm{log} \mathrm{cfu} / \mathrm{ml}$ below the detection limit. No regrowth occurred during the 48 -h treatment period. In another experiment, the effect of amikacin treatment was studied against bacteria in the stationary phase of growth in PBS-S. After $6 \mathrm{~h}$ of exposure to amikacin Aq8, S. epidermidis V2 was killed by $>5.9 \log \mathrm{cfu} / \mathrm{ml}$. In contrast, the number of cfu remained stable over this period in a control experiment. In summary, experiments with released or nongrowing inocula revealed results similar to the data obtained in TSB-S using standard suspended inocula (figure 5).

In contrast, the intermediately sensitive strain B3972 was initially reduced by amikacin only by 2.7 (Aq8) and $3.3 \mathrm{log}$ $\mathrm{cfu} / \mathrm{ml}$ (Aq24, figure 6), and regrowth to densities above the

Table 1. Change of bacterial counts in log colony-forming units (cfu) after 48 -h treatment of inocula administered in suspension or as biofilm adhering to solid or sinter glass beads.

\begin{tabular}{|c|c|c|c|c|c|c|c|c|c|c|c|c|c|}
\hline \multicolumn{3}{|c|}{ Aq8 } & \multicolumn{3}{|c|}{$\mathrm{Aq} 24$} & \multicolumn{3}{|c|}{$\begin{array}{c}\beta \text {-lactam } \\
\text { (continuous infusion) }\end{array}$} & \multicolumn{3}{|c|}{$\mathrm{Aq} 8+\beta$-lactam } & \multicolumn{2}{|c|}{$\mathrm{Aq} 24+\beta$-lactam } \\
\hline & Adh & erent & & Adh & erent & & Adr & erent & & Adh & erent & & Adherent \\
\hline Suspended & Solid & Sinter & Suspended & Solid & Sinter & Suspended & Solid & Sinter & Suspended & Solid & Sinter & Suspended & Solid Sinter \\
\hline
\end{tabular}

\begin{tabular}{|c|c|c|c|c|c|c|c|c|c|c|c|c|c|c|c|}
\hline \multicolumn{16}{|c|}{$\begin{array}{l}\text { Pseudomonas } \\
\text { aeruginosa }\end{array}$} \\
\hline 27853 & 0.3 & 0.1 & -0.3 & 0.2 & -0.1 & -0.6 & -5.2 & ND & $-1.2^{*}$ & $-5.5^{+}$ & ND & $-4.9^{\prime \ddagger}$ & $-5.5^{\dagger}$ & ND & $-5.0^{t t}$ \\
\hline S64 & -1.4 & -0.1 & -0.2 & -1.5 & 0.3 & -0.2 & $-4.4^{\dagger}$ & -3.3 & -2.3 & $-4.9^{\dagger}$ & ND & $-5.2^{\ddagger \ddagger}$ & $-4.8^{\dagger}$ & ND & $-5 . \mathrm{I}^{\mathrm{tt}}$ \\
\hline \multicolumn{16}{|c|}{$\begin{array}{r}\text { Staphylococcus } \\
\text { epidernidis }\end{array}$} \\
\hline $\mathrm{V} 2$ & $-5.8^{\dagger}$ & $0.8^{*}$ & ND & $-5.7^{\dagger}$ & $0.7^{*}$ & $0.5^{*}$ & $-5.9^{\dagger}$ & $-5.8^{\dagger}$ & $-6.2^{\dagger}$ & $-6.1^{\dagger}$ & $-5.7^{\dagger}$ & ND & $-6.0^{\dagger}$ & $-5.4^{\dagger}$ & $-6.2^{+}$ \\
\hline В3972 & 0.5 & ND & 0.0 & 0.2 & ND & 0.1 & $-6.3^{\dagger}$ & ND & $-0.9^{*}$ & $-6.2^{\dagger}$ & ND & $-6.0^{ \pm}$ & $-6.3^{+}$ & ND & -3.9 \\
\hline
\end{tabular}

NOTE. Aq 8 = amikacin given thrice daily; Aq24 = amikacin given once daily; suspended = suspended cfu, inoculation as suspended culture; adherent, solid = adherent $\mathrm{cfu}$. inoculation as biofilm on solid glass beads: adherent, sinter = adherent cfu, inoculation as biofilm on sinter glass beads; $\mathrm{ND}=$ not done.

* Significantly $(P<.01)$ better bactericidal activity against suspended inocula compared with adherent inocula.

$\dagger$ Eradicated below detection limit of $10 \mathrm{cfu} / \mathrm{ml}$.

‡ Significantly $(P<.01)$ better bactericidal activity of combinations compared with single-drug regimens. 


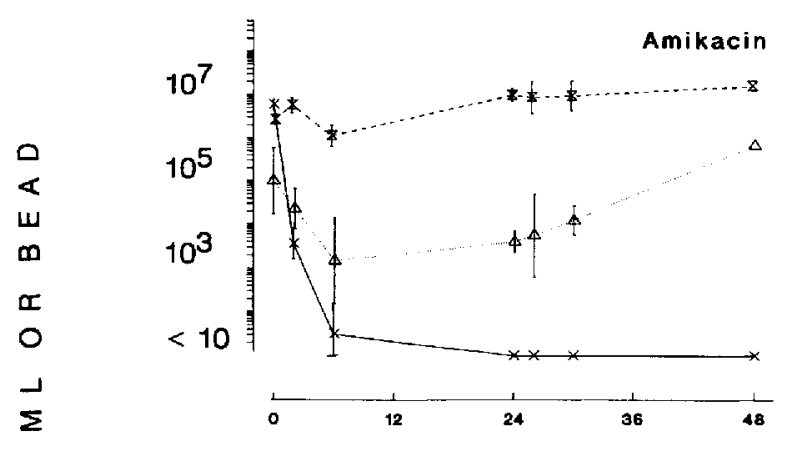

ar

w

a.

$\infty$

1

$\bar{z}$

$\supset$

5

$z$

$\bar{\Sigma}$

$\infty$

O

ᄂ

2

0

0
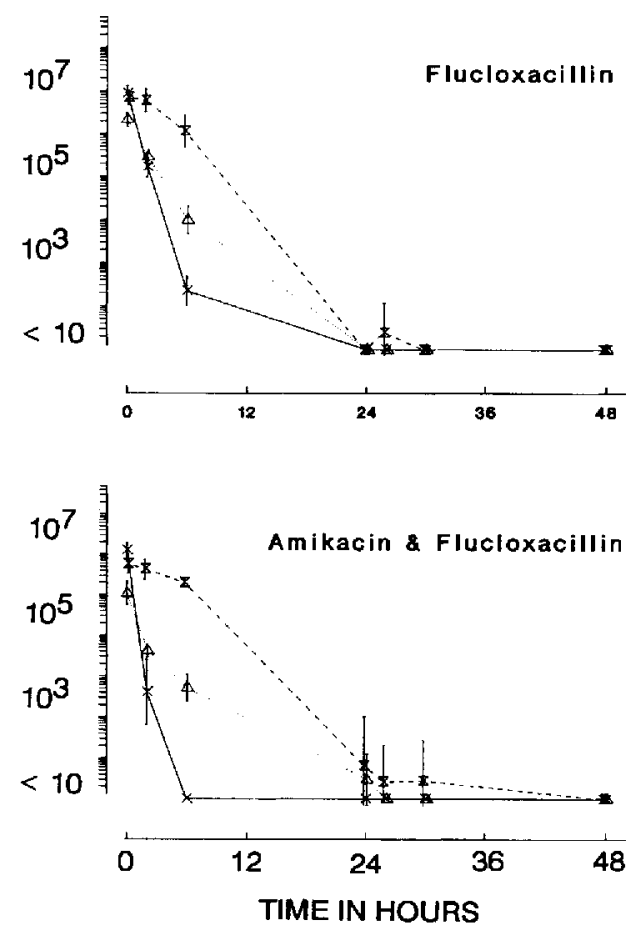

Inoculum

\section{Colony forming units}

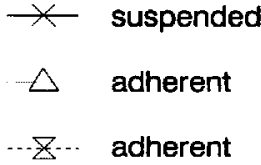

suspended

suspended

adherent

Figure 5. Effect of amikacin (thrice daily), flucloxacillin (loading dose followed by continuous infusion), and combination of both drugs on Staphylococcus epidermidis V2 in one-compartment in vitro model. Significantly $(P<.01)$ better initial activity was observed in experiments with suspended inocula (colony-forming units per milliliter $[\mathrm{cfu} / \mathrm{ml}]$ in broth) compared with adherent inocula $(\mathrm{cfu} / \mathrm{ml}$ bacteria shed from adherent population into culture medium and adherent cfu per solid glass bead). Geometric means and SD of two or three replicates are shown.

inoculum occurred with both regimens. Flucloxacillin alone and in combination with $\mathrm{Aq} 8$ and $\mathrm{Aq} 24$ produced rapid initial killing and reduced the inocula of both strains after $24 \mathrm{~h}$ below the detection limit with no subsequent regrowth (figures 5 and 6 ).
Adherent inocula of $S$. epidermidis. In contrast to data observed with suspended inocula, little initial killing was observed with amikacin given as single agent against adherent bacteria (with Aq8 and Aq24, 0.4 and $1.2 \log$ reduction of strain V2, respectively; with Aq8 and Aq24, 0.7 and $1.6 \log$ reduction of strain B3972, respectively). Subsequent doses had no effect (figures 5 and 6 ). The dose response to flucloxacillin differed between the two strains, reflecting different sensitivities. Adherent bacteria of the highly sensitive strain $\mathrm{V} 2(\mathrm{MIC}=0.25 \mathrm{mg} / \mathrm{l})$ were killed slowly and steadily. After $30 \mathrm{~h}$ of treatment, inocula were reduced below the detection limit and no regrowth occurred (figure 5 ). The less-sensitive strain B3972 (flucloxacillin MIC $=1 \mathrm{mg} / \mathrm{l}$ ) showed almost no response to treatment with a loading dose of flucloxacillin followed by continuous infusion of two times the MIC (0.9 $\log$ reduction over $48 \mathrm{~h}$, figure 6 ). In additional experiments using four-times-higher concentrations of flucloxacillin (eight times the MIC), response was similar to that of strain V2, with rapid bactericidal effect followed by no regrowth.

In contrast to the synergistic effect observed during combination treatments of strain V2 on initial killing of suspended bacteria, the combination did not kill adherent bacteria more rapidly than flucloxacillin alone (figure 5). Combination treatment of strain B3972 produced synergistic killing of adherent bacteria, but the inocula were not yet completely eradicated after 48 h of treatment (figure 6, table 1).

Suspended bacteria shed from biofilm-covered glass beads responded better to the antibiotic treatments than did adherent bacteria. However, the response was less pronounced compared with suspended bacterial cultures in the absence of adherent inocula (figures 5 and 6). The initial dose of each regimen killed $95 \%-99.99 \%$ of the inocula of both strains within $6 \mathrm{~h}$. In contrast, doses administered after $24 \mathrm{~h}$ were not effective ( $<1$ log killing) except for the Aq24 regimen against strain V2 (3.3 log killing followed by regrowth).

Effect of structure of glass beads. Two types of glass beads were used to study the effect of the structure of the beads on the bactericidal activity of amikacin, ceftazidime, and flucloxacillin against adherent $P$. aeruginosa and $S$. epidermidis.

Biofilms with higher bacterial numbers adhered to the beads with $S$. epidermidis compared with $P$. aeruginosa (table 2 ). The number of cfu adhering to solid glass beads were 0.5 $\log (S$. epidermidis $)$ and $1.1 \log (P$. aeruginosa $)$ lower than those on sinter glass beads after $20 \mathrm{~h}$ of incubation in a test tube. Twelve of these beads were used for inoculation of each compartment.

Only minor differences were observed during antibiotic treatment of biofilms adhering to either solid or sinter glass beads. After $48 \mathrm{~h}$ of treatment, differences did not exceed 1 $\log$ in the eight sets of experiments in which both types of beads were studied (table 1).

Postexposure susceptibility testing. Subpopulation analysis was done during exposure of $P$. aeruginosa $\mathbf{S 6 4}$ to ceftazidime by direct subculturing of specimens on an agar plate containing ceftazidime one, two, or four times the MIC. No 


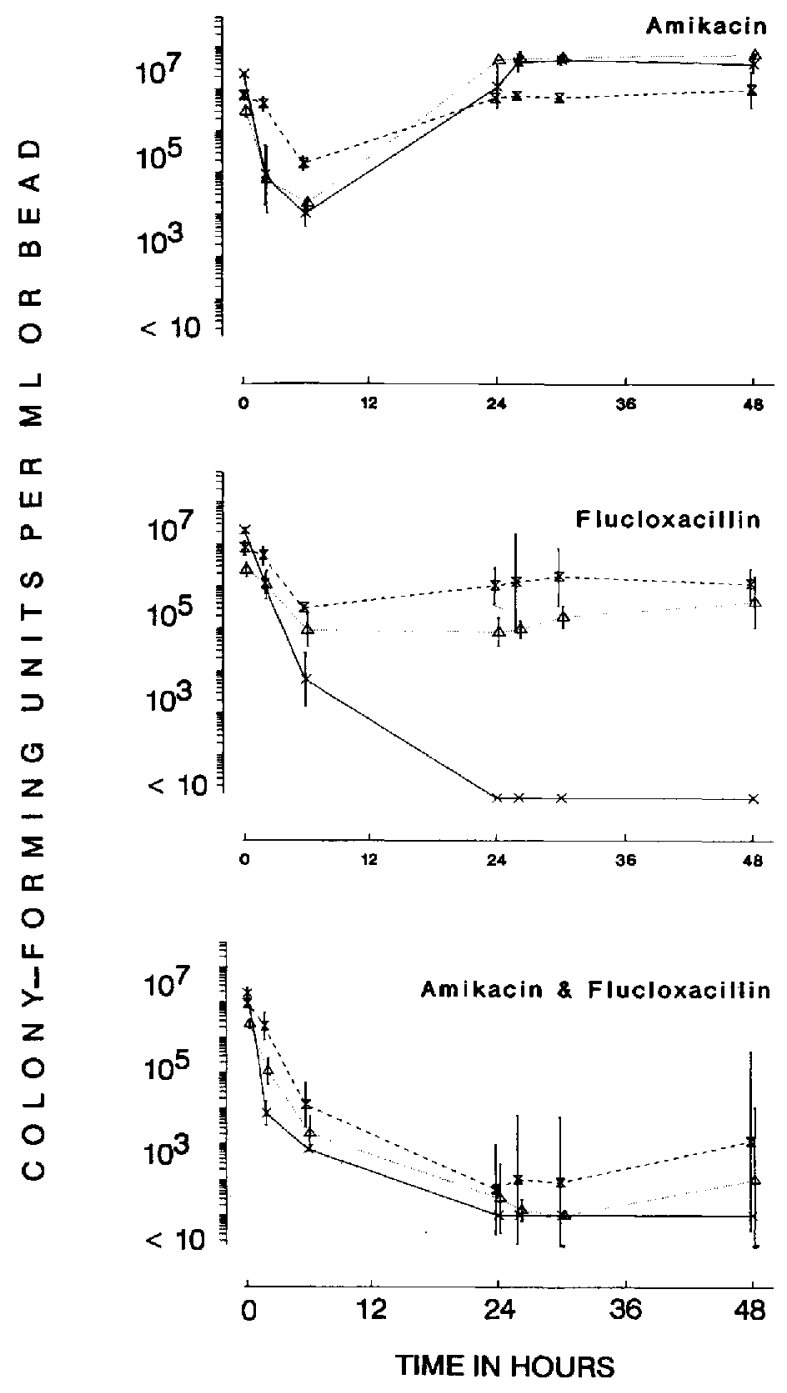

$\begin{array}{lll} & \text { Inoculum } & \text { Colony forming units } \\ \times \quad \text { suspended } & \text { suspended } \\ \triangle & \text { adherent } & \text { suspended } \\ \cdots \square \cdots & \text { adherent } & \text { adherent }\end{array}$

Figure 6. Effect of amikacin (once daily), flucloxacillin (loading dose followed by continuous infusion), and combination of both drugs on Staphylococcus epidermidis B3972 in one-compartment in vitro model. Effect was studied in experiments with suspended inocula (colony-forming units per milliliter $[\mathrm{cfu} / \mathrm{ml}]$ in broth) or adherent inocula ( $\mathrm{cfu} / \mathrm{ml}$ bacteria shed from adherent population into culture medium and adherent cfu per solid glass bead). Geometric means and SD of two or three replicates are shown.

resistant subpopulation of adherent bacteria or of shed suspended bacteria was detected on ceftazidime-containing plates after $0,6,24$, and $48 \mathrm{~h}$.

Subpopulation analysis were also done during amikacin (Aq8) treatment of $S$. epidermidis V2. Lower bactericidal ac- tivity observed against adherent than against shed suspended bacteria did not correlate with a higher percentage of resistant subpopulations in the adherent bacteria. In fact, after 24 $\mathrm{h}$ of exposure, a significantly higher percentage of resistant subpopulations was found in suspended bacteria shed from biofilm (24\% of bacterial population resistant to 1 and $4 \mathrm{mg} / \mathrm{l}$ of amikacin) compared with adherent bacteria (2.8\% resistant to $1 \mathrm{mg} / \mathrm{l}$ and $1.4 \%$ resistant to $4 \mathrm{mg} / \mathrm{l}$; mean of triplicate experiments, $P<.001$ ). After $48 \mathrm{~h}$ of treatment, $43 \%$ of shed bacteria were resistant to $1 \mathrm{mg} / \mathrm{l}$ and $38 \%$ to $4 \mathrm{mg} / \mathrm{l}$ compared with adherent bacterial populations with $11 \%$ resistant to $I$ $\mathrm{mg} / \mathrm{l}$ and $9.4 \%$ to $4 \mathrm{mg} / \mathrm{l}$. No subpopulations of shed suspended or adherent bacteria were resistant to $16 \mathrm{mg} / \mathrm{l} \mathrm{of} \mathrm{ami-}$ kacin after $24 \mathrm{~h}$ and $<0.02 \%$ at the end of the 48 -h treatment period.

Assessment of removal of adherent bacteria. After the vortexing and washing procedure of solid glass beads initially covered with radiolabeled bacterial biofilms, the radioactivity was reduced to $3.5 \%$ of the initial activity for $S$. epidermidis V2 and $1.0 \%$ for $P$. aeruginosa 27853 . The respective results for biofilms grown on sinter glass beads were $8.1 \%$ for S. epidermidis B3972 and 0.2\% for P. aeruginosa S64.

\section{Discussion}

A novel method has been developed to expand the study of in vitro activity of antimicrobial agents against both suspended and adherent bacteria in the presence of clinically relevant pharmacokinetic profiles. Important differences were observed in the dose response of adherent compared with suspended bacteria. Although amikacin was rapidly bactericidal against suspended pseudomonads and staphylococci, no or only limited bactericidal effect occurred during treatment of adherent bacteria. Similarly, the activity of ceftazidime was compromised when pseudomonads were adherent instead of suspended. However, adherence did not protect bacteria from the lethal activity of the $\beta$-lactamaminoglycoside combination, although killing was somewhat delayed. Flucloxacillin alone was rapidly bactericidal against suspended staphylococci and also eradicated adher-

Table 2. Effect of structure of glass beads on bacterial inoculum adhering as a biofilm after overnight inoculation.

\begin{tabular}{lcc}
\hline & Solid glass beads & Sinter glass beads \\
\hline $\begin{array}{l}\text { Pseudomonas aeruginosa } \\
27853\end{array}$ & $5.1 \pm 0.5$ & \\
S64 & $4.7 \pm 0.7$ & $6.2 \pm 0.3$ \\
Staphylococcus epidermidis & & $5.8 \pm 0.2$ \\
V2 & $6.7 \pm 0.4$ & \\
B3972 & $6.3 \pm 0.4$ & $7.1 \pm 0.1$ \\
\hline
\end{tabular}

NOTE. Data are log colony-forming units per glass beads (geometric mean $\pm \mathrm{SD}$ of replicates obtained in 12 experiments). 
ent bacteria during exposure to eight but not two times the MIC.

The compromised activity of antibiotics against adherent bacteria might relate to an inoculum effect, to the development of resistance, to altered susceptibility due to the slow growth of the adherent populations (figure 2), or to protection of biofilm-embedded bacteria due to reduced antibiotic penetration through the extracellular slime. In this study, suspended inocula were adjusted to provide total numbers of suspended bacteria within the compartments that were about two times higher than the bacterial numbers inoculated by adherent biofilms. Thus, lower activity against adherent inocula did not relate to an inoculum effect.

Subpopulation analysis of amikacin against $S$. epidermidis V2 and ceftazidime against $P$. aeruginosa $\mathbf{S 6 4}$ revealed no evidence that more resistant subpopulations existed in adherent than in suspended bacteria. The comparative experiments of amikacin acting on $S$. epidermidis V2 in either TSB$S$ or PBS-S suggest that the compromised activity against adherent bacteria can occur during exposure of either growing or nongrowing bacteria. However, it cannot be excluded that experiments with nongrowing suspended bacteria cultured in PBS-S do not truly reflect the effect of the slow growth rate of the adherent population within the biofilm due to possible differences in metabolic activity of the suspended and adherent cells. Nevertheless, the data obtained support the concept that the compromised activity against adherent bacteria relates to protection of bacteria embedded in the biofilm. Destruction of the biofilm and release of the adherent bacteria into suspension by vortexing revealed results similar to those of experiments using suspended overnight cultures as inocula; however, the release of adherent cells by destruction of the biofilm might create new metabolic conditions within minutes, allowing bacteria to change their own synthesis and catabolism.

The observations of reduced activity against shed suspended bacteria do not suggest reduced susceptibility of individual shed organisms. Changes of the population of shed suspended organisms during treatment represent the increase of the population due to continuous release of adherent bacteria from the biofilm into the culture medium minus the ongoing killing of suspended bacteria by the antibiotics. Thus, the intermediate treatment response of shed suspended bacteria reflects the mixed effect against adherent and suspended populations.

Rapid bactericidal activity has been demonstrated by various in vitro methods during exposure of high inocula of suspended bacteria to suprainhibitory concentrations of aminoglycosides and $\beta$-lactams [14]. Similarly, only short treatment periods are required to either eradicate or drastically reduce the pathogens in many animal models that provide short treatment-free periods between inoculation of bacteria in suspension and the onset of therapy [16-18]. In contrast, in vivo models of chronic infections and most severe clinical infections in humans require a prolonged treat- ment for cure. Thus, the slow bactericidal effect observed with in vitro models for the study of antibiotic activity against adherent bacteria might relate more closely to the clinical situation than antibiotic exposure of suspended cultures. In fact, several histologic studies suggest that populations of adherent organisms can be found in infected patients not only on implanted devices, but also on catheters, native heart valves, or bone structures $[7,8,19,20]$.

Aminoglycoside treatment providing peak concentrations of at least 10 times the MIC has been found previously and in this study to be bactericidal in in vitro models of infection against suspended gram-negative and -positive bacteria [21, 22]. In the present study, however, amikacin administered alone against adherent inocula produced no bactericidal effect after $24 \mathrm{~h}$ of treatment despite peak-to-MIC ratios of up to 72 . These data suggest insufficient intrinsic activity of aminoglycosides for single-drug treatment of infections with established populations of adherent bacteria.

The in vitro model presented here simulates antibiotic treatment of a bacterial infection in the absence of any cellular or humoral host defense. However, in foreign-body infections, adherent bacteria have been found to be resistant to killing by polymorphonuclear leucocytes [23]. Extracellular slime found in bacterial biofilms also appears to interfere with various host-defense mechanisms [15, 24-27]. Thus, the model may be considered as an in vitro simulation of antibiotic treatment of foreign-body infections.

Major differences in the in vitro activity of antibiotics have been observed at clinically achievable concentration profiles against suspended and adherent bacteria. These data may relate to clinical failures in the treatment of implant-related infection caused by bacteria that are sensitive to the administered antibiotics as determined by standard susceptibility tests. Information obtained with this in vitro model may contribute in concert with studies in animal models to further development of rational hypothesis on optimal antibiotic therapy. Ultimately such concepts need to be verified or disproved by the reference standard, clinical studies.

\section{References}

I. Widmer AF, Frei R, Rajacic Z. Zimmerli W. Correlation between in vivo and in vitro efficacy of antimicrobial agents against foreign body infections. J Infect Dis 1990;162:96-102.

2. Anwar H. Dasgupta MK, Costerton JW. Testing the susceptibility of bacteria in biofilms to antimicrobial agents. Antimicrob Agents Chemother 1991;34:2043-6.

3. Anwar H, van-Biesen T. Dasgupta M, Lam K, Costerton JW. Interaction of biofilm bacteria with antibiotics in a novel in vitro chemostat system. Antimicrob Agents Chemother 1989;33:1824-6.

4. Costerton JW, Cheng KJ, Geesey GG, et al. Bacterial biofilms in nature and disease. Annu Rev Microbiol 1987:4 1:435-64.

5. Gristina AG. Biomaterial-centered infection: microbial adhesion versus tissue integration. Science 1987;237:1588-95.

6. Gristina AG, Jennings RA, Naylor PT, Myrvik QN, Webb LX. Comparative in vitro antibiotic resistance of surface-colonizing coagulase- 
negative staphylococci. Antimicrob Agents Chemother 1989; 33:813-6.

7. Hamill RJ. Role of fibronectin in infective endocarditis. Rev Infect Dis 1987:9:360-70.

8. Mayberry-Carson KJ, Tober-Meyer B, Lambe DW Jr, Costerton JW. An electron microscopic study of the effect of clindamycin therapy on bacterial adherence and glycocalyx formation in experimental Staphylococcus aureus osteomyelitis. Microbios 1986;48:189-206.

9. Christensen GD. Simpson WA, Bisno AL, Beachey EH. Experimental foreign body infections in mice challenged with slime-producing Staphylococcus epidermidis. Infect Immun 1983;40:407-10.

10. Zimmerli W, Waldvogel FA, Vaudaux P, Nydegger UE. Pathogenesis of foreign body infection: description and characteristics of an animal model. J Infect Dis 1982;146:487-97.

11. Anwar H, Dasgupta M, Lam K, Costerton JW. Tobramycin resistance of mucoid Pseudomonas aenginosa biofilm grown under iron limitation. J Antimicrob Chemother 1989;24:647-55.

12. Blaser $J$, Weinmann $O$, Lüthy $R$. Poor antibiotic activity against adherent bacteria [abstract 782]. In: Program and abstracts of the 28th Interscience Conference on Antimicrobial Agents and Chemotherapy (Los Angeles). Washington. DC: American Society for Microbiology, 1988.

13. Blaser J, Stone BB, Zinner SH. Two compartment kinetic model with multiple artificial capillary units. J Antimicrob Chemother 1985; 15(suppl A):131-7.

14. Blaser I, Zinner SH. In vitro models for the study of antibiotic activities. Prog Drug Res 1987;31:349-81.

15. Johnson GM. Lee DA, Regelmann WE. Gray ED, Peters G, Quie PG. Interference with granulocyte function by Staphylococcus epidermidis slime. Infect Immun 1986;54:13-20.

16. Davey PG. Barza M, Stuart M. Dose response of experimental Pseudomonas endophthalmitis to ciprofloxacin, gentamicin, and imipenem: evidence for resistance to "late" treatment of infections. J Infect Dis 1987:155:518-23.

17. Gerber AU, Bangerter T, Greter U, Feller C. Impact of bacterial inoculum size and initial treatment free interval on antimicrobial efficacy in vivo [abstract 573]. In: Program and abstracts of the 26th Inter- science Conference on Antimicrobial Agents and Chemotherapy (New Orleans). Washington, DC: American Society for Microbiology, 1986.

18. Roosendaal R. Bakker-Woudenberg IAJM, van den Berg JC, Michel MF. Therapeutic efficacy of continuous versus intermittent administration of ceftazidime in an experimental Klebsiella pneumoniae pneumonia in rats. J Infect Dis 1985:1 52:373-8.

19. Peters G. Pulverer G. Pathogenesis and management of Siaphylococcus epidermidis 'plastic' foreign body infections. J Antimicrob Chemother 1984; 14(suppl D):67-71.

20. Read RR, Eberwein P. Dasgupta MK, et al. Peritonitis in peritoneal dialysis: bacterial colonization by biofilm spread along the catheter surface. Kidney Int 1989;35:614-21.

21. Blaser J. Efficacy of once- and thrice-daily dosing of aminoglycosides in in-vitro models of infection. J Antimicrob Chemother 1991; 27(suppl C):2l-8.

22. Blaser J, Stone BB, Groner MC, Zinner SH. Impact of netilmicin regimens on the activities of ceftazidime-netilmicin combinations against Pseudomonas aeruginosa in an in vitro pharmacokinetic model. Antimicrob Agents Chemother 1985;28:64-8.

23. Jensen ET, Kharazmi A. Lam K, Costerton JW, Hoiby N. Human polymorphonuclear leukocyte response to Psendomonas aeruginosa grown in biofilms. Infect Immun 1990;58:2383-5.

24. Falcieri E, Vaudaux P, Huggler E, Lew D, Waldvogel F. Role of bacterial exopolymers and host factors on adherence and phagocytosis of Staphylococcus aureus in foreign body infection. J Infect Dis 1987;155:524-31.

25. Peters G. New considerations in the pathogenesis of coagulase-negative staphylococcal foreign body infections. J Antimicrob Chemother 1988;21(suppl C): 139-48.

26. Vaudaux PE, Zulian G, Huggler E. Waldvogel FA. Attachment of Staphylococcus aureus to polymethylmethacrylate increases its resistance to phagocytosis in foreign body infection. Infect Immun 1985:50:472-7.

27. Zimmerli W. Lew PD, Waldvogel FA. Pathogenesis of foreign body infection. Evidence for a local granulocyte defect. J Clin Invest 1984; 73:1191-200. 